\title{
The Role of the Faculties of Shariah in Jordanian Public Universities in Promoting Moderate Ideologies Among Students
}

\author{
Musa Abdullah Hassan Al Haj Ali Prof. Natheer Sihan Mohammad Abu Nair \\ Department of Education Science, Al - Balqa Applied University, Princess Rahma College
}

\begin{abstract}
The present study aimed to explore the role of the faculties of Shariah in Jordanian public universities in promoting moderate ideologies among students. It aimed to explore this role in several areas: (teaching, scientific research, curricula, and training programs \&student activity). It aimed to explore that from the graduate students' perspective. The researchers selected a simple random sample consisting from 334 female and male students. This sample was selected from the faculties of Shariah in three Jordanian universities; the University of Jordan, Yarmouk University and Mu'tah University. The researchers developed a forty eight (48) item questionnaire that sheds a light on four (4) areas. It was found that the faculties of Shariah in Jordanian public universities play a moderate role in promoting moderate ideologies among students, because the total mean is 3.44 . The curricula area is ranked first due to showing a mean of 3.73 which is high. The teaching -curricula is ranked second, due to showing a mean of 3.50 which is moderate. The scientific research area is ranked third due to showing a mean of 3.44 which is moderate. The (training programs \&student activity) area is ranked fourth due to showing a mean of 2.87 which is moderate. In the light of the study's results, several recommendations were suggested. For instance, the researchers recommend activating the role of the faculties of Shariah in Jordanian public universities in promoting moderate ideologies among students. Such activation must involve several areas: (teaching, scientific research, curricula, and training programs \&student activity).The researchers recommend increasing the cooperation between the faculties of Shariah in Jordanian universities in order to suggest practical solutions for addressing the problems hindering those universities from promoting moderate ideologies among students.
\end{abstract}

Keywords: moderate ideologies, Faculty of Shariah

DOI: $10.7176 / \mathrm{JEP} / 11-3-17$

Publication date: January $31^{\text {st }} 2020$

\section{Introduction}

Countries seek achieving development and growth in all areas. They aim at achieving happiness and welfare for their citizens to have a healthy society. That can be achieved through promoting positive ideologies. Promoting positive ideologies can promote creativity among people. It participates in achieving development. It enables people to cope with the surrounding environment to survive. Countries have been sharing information about ideologies. In each country, there are educational institutions that play a significant role in promoting values, beliefs, and ideas.

Such educational institutions include schools. Schools carry out this role through the lessons and activities that are listed in curricula. Such educational institutions include universities. Today, universities play a significant role in achieving development and advancement in societies. The creation of universities and the introduction of several new university academic programs support people's right to think and adopt ideologies freely. They meet the social, cultural and intellectual needs of individuals and societies. Today, higher education institutions play a significant role in developing knowledge. They carry out this function through carrying out various intellectual and scientific. Such institutions also play a significant role in cultural and intellectual area in society (E'baidat, 2014).

Through conducting studies, researchers and specialists have been providing much attention to universities and their educational and intellectual functions. The role of universities has developed in several scientific and technical areas. It has developed in addressing various social, cultural, and political changes. Universities play a significant role in handling community problems and utilizing knowledge to gain economic, political and intellectual power. Gaining such power shall enable universities to fight against radicalism. Researchers and specialists have been giving much attention to universities. For instance, there are various studies that address university-relate issues. Some of those studies address the image of universities from a philosophical perspective. Some of those studies shed a light on faculty members' role and research, intellectual, mental and cognitive capabilities. Such capabilities enable faculty members to carry out their educational roles (Al-Bura'y, 2002).

Universities aim at promoting ideas, and values and shaping people's behaviors. They play a significant role in promoting religious values. They carry out such functions through teaching students and educating them in accordance with the principles of Islam (Al-Maqousi and Fatheye, 2013).

Islam aims at promoting moderate ideologies. The principles of Islam are suitable for each era and place. That applies till the judgment day comes. The moderation of Islam can be manifested through Aqidah, Shariah, and Islamic values. It can be manifested through the way in which Islam regulates transactions and relationships. For 
instance, Islam involves much tolerance and acceptance. The moderation of Islam can be manifested through Quran, Sunah and the practices of Islam. It can be manifested through the way in which Islam regulates various aspects of life (Abu Al-Hasan, 2015).

Moderation is a principle that applies to daily life. It's one of the pillars of Islam. It governs this universe. It governs the way of practicing the religious duties of Islam. In other words, one mustn't show negligence nor excessiveness when carrying out the religious rituals of Islam. Showing negligence in this regard is similar to showing excessiveness. The Muslim nation is the best nation among nations as Prophet Mohammad said. Thus, it is entitled to be a leading nation. It's entitled to be so due to the attributes that characterize it. Such attributes include moderation in all aspects. Moderation in Islam serves as a comprehensive approach. It can be manifested through all the rules, and Ahkam of Islam. If Islam was adopted correctly, it can be adopted in any place and time due to being moderate (Al-Farfour, 2002).

The Muslim nation leads other nations, instead of being led by a nation. Its moderation can be manifested through the beliefs it adopts. It treats others in a fair manner. It adopts moderation through refraining from showing negligence or exaggeration in order to avoid causing damage to itself and others. Islam adopts moderation through achieving a balance between meeting the needs of the soul and body, individual and society, and life and after life. It adopts moderation through achieving a balance between meeting the materialistic and spiritual needs. Moderation in Islam is not a new approach or concept in Islam. In fact, it has been always existent in Islam. The Muslims who want to please Allah should adopt moderation. Through adopting moderation, one shouldn't show oppression, nor radicalism, nor give up. Through understanding the moderation of Islam, one shall become capable to understand Islam correctly and realize that Islam is based on achieving balance in everything (Al-Sultani, 2011).

Islam spread much and many foreigners adopt it. At some point, the Islamic nation was living in the golden age. Muslims translated various books written by people in other nations. They studied well the Greek philosophy. They interacted directly with other nations. That led to the spread of new ideas among people in the Muslim society. Therefore, some people in the Muslim society started to adopt some modern ideas with keeping other conventional ideas. It should be noted that several Islamic groups emerged. That led to the emergence of radicalism in various aspects of life; political; cultural and religious areas (Badawi, 1999).

In the light of that, much effort has been exerted to fight against radicalism and promote an Islamic moderate ideology. Scholars have been playing an important role in promoting this ideology (Al-Ameery, 2007).

Many technological and scientific developments have been made. In the light of that, educational institutions -like schools and universities- have become responsible for promoting an Islamic moderate ideology. This role should be carried out by the faculty of shariah and its faculty members. The faculty of Shariah aims at developing students' personalities and instilling Islamic values within students. It aims at developing students in physical, mental, intellectual and social aspects. It participates in developing knowledge and utilizing it for serving society. It aims at promoting awareness about religious, cultural and intellectual issues in accordance with the Islamic principles. It aims at doing that to meet the needs of nations and affect their behaviors positively. Achieving that by the faculty of Shariah requires developing students in order to become capable to carry out those duties and handle responsibilities. Therefore, the faculty members at the faculty of Shariah have many responsibilities. They play a significant role, especially in addressing issues that concern the local society and achieving development (Al-Khayat, 1994)

In the light of making many scientific and technological developments, the role of faculty member has become complex. For instance, the faculty member today isn't just responsible for conducting studies, gaining much knowledge about his major and teaching courses. In fact, he has become responsible for educating good citizens who are qualified in scientific and intellectual areas. The contemporary role of faculty member plays a major role in society. That's because such a role affects people's attitudes, and the society's capability to handle problems and meet goals.

The students enrolled in a faculty of Shariah aim at making reforms in society and doing good deeds. They aim at defending Islam and its image. They aim at carrying out their duties as good Muslims and promoting a good image about Islam. That's because they have devoted themselves for defending Islam). Those students carry out this role because they realize the significant role of education in developing society. For instance, education aims at enriching people's knowledge and developing their skills and expertise. It enables people to carry out the duties assigned to them perfectly.

Nawab Al-Deen (1995) suggests that Muslims today are in need for true advice delivered by visionary expert Muslims. He adds that Muslim preachers must aim at achieving reform in the Muslim nation. He adds that Allah encouraged Muslims to carry out reforms in order to avoid disasters. For instance, a verse in Quran states the following: (Your Lord would never destroy the villages unjustly, whilst their people were reforming) (Hood Surah, 117).

The role of the faculty of Shariah isn't limited anymore to the identification of Islamic principles and facts. In fact, the latter faculty has become responsible for promoting knowledge about Islam (Al-Mudwadi, 1986, p.27the right Islamic practices that meet the needs of society and develop it. However, doing that requires 
promoting moderate ideologies and encouraging people to stop doing sins for meeting their desires (Al-Farfour, 2002).

Many researchers (e.g. Almasri, 2001) suggest that they aren't satisfied about the way the students of the faculty of Shariah make reforms in society. They consider those students as weak, and lacking vision. That led to weakening the capability of the faculty of Shairah to keep up with the developments. Alomari (2009) describe those students as being imitative, not innovative and refrain from exerting effort and do not think.

In simple words, the students and faculty members at the faculty of shariah must promote awareness in society about the moderate ideology of Islam. Such an ideology aims at achieving balance when meeting the needs of body and spirit and mind and desires. Islam regulates all the aspect of life and no one can prefer adopting a certain Islamic rule with excluding other rules.

To sum up, the faculty of Shariah is responsible for carrying out educational service and intellectual duties. Therefore, it's necessary to develop the students enrolled at the latter faculty in order to develop the nation (AlAmeery, 2007).

Developing the nation requires having scholars in religion who carry out their duties perfectly. The faculty members and students of the faculty of Shariah are responsible for promoting knowledge about the moderate ideology of Islam and fighting radicalism. That's because the misinterpretation of Islamic texts led to the spread of radical ideologies. The latter faculty members and students are responsible for suggesting educational mechanisms for promoting the moderate ideology of Islam. Handling such responsibilities shall activate the role of those faculty members and students in serving their nation.

\section{Statement of the problem and the Study's Questions:}

Education plays a significant role in changing people's behaviors. Thus, it plays a significant role in achieving development and advancement. It enables institutions- including universities- to achieve development. It plays a significant role in shaping the ideologies of the members of society. Several changes have been facing the Islamic world. Many radical ideas and practices have been spreading in the Islamic society. Therefore, it is necessary to activate the role of the faculties of Shariah in fighting against radicalism and excessiveness. That can be done through educating people and enabling them to serve their Islamic nation.

The researchers of this study aimed to shed a light on the role of the faculty of Shariah in society. They aimed to identify the methods that help the students and faculty members of this faculty in doing their duties. Such duties include: promoting moderate ideologies and true image about Islam among people. To be more specific, the present study aimed to explore the role of the faculties of Shariah in Jordanian public universities in promoting moderate ideologies among students. It aimed to provide an answers to this question:

What's the role of the faculties of Shariah in Jordanian public universities in promoting moderate ideologies from the perspective of graduate students?

\section{The Study's Objective:}

The present study aimed to explore the role of the faculties of Shariah in Jordanian public universities in promoting moderate ideologies among students. It aimed to explore that in several areas: (teaching, scientific research, curricula, and training programs \&student activity). It aimed to explore that from the graduate students' perspective.

\section{The Study's Significance}

This study shall benefit the following categories:

Decision makers: This study shall provide policymakers and decision makers in Jordanian public universities with knowledge that participates in developing the curricula of the faculties of Shariah. This knowledge shall participate in developing the adopted teaching methods and activities that aim at promoting the moderate ideology of Islam. That shall positively affect society.

Researchers: This study shall serve as a reference in the studies conducted about the faculty of Shariah in promoting moderate ideology among people. It shall participate in filling a gap in the relevant literature due to the scarcity of the relevant studies.

- University students: This study shall participate in educating students who realize their role in society. Such role include promoting a true image about Islam and its moderate ideology. That shall activate the role of students in fighting against radicalism.

\section{Theoretical definitions:}

Role: It refers to a set of activities that are carried out intentionally in accordance with specific standards. Such activities can be assessed. It may refer to a set of behaviors that one is expected to carry out to get a specific social status in society (Husam and Ma'bad, 2003: p.288).

Moderate ideology: It refers to an ideology that is derived from the Holy Quran and Sunah. It's represented in not showing excessiveness nor negligence. It can be manifested through the way in which Islam regulates 
transactions, worships and relationships.

\section{Operational definitions:}

Role: It refers to a set of activities, duties, practices and procedures that should be carried out by the faculties of Shariah in public Jordanian universities in order to promote the moderate ideology of Islam.

\section{Limits and limitations}

This study aimed to explore the role of the faculties of Shariah in Jordanian public universities in promoting moderate ideologies among students. It aimed to explore that in several areas: (teaching, scientific research, curricula, and training programs \&student activity). It aimed to explore that from the graduate students' perspective. The study's limits are listed below:

Thematic limits: This study sheds a light on the role of role of the faculties of Shariah in Jordanian public universities in promoting moderate ideologies among students.

Human limits: This study sampled several graduate students selected from the faculties of Shariah in Jordanian public universities.

Spatial limits: This study was conducted in the faculties of Shariah in three Jordanian public universities; the university of Jordan, Yarmouk University and Mu'tah University.

Temporal limits: This study was conducted during the first semester of the academic year of 2019-2020.

\section{Previous Studies}

Asalabi (2001) conducted a study targeting (Moderation in the Holy Quran). An analytical descriptive approach was adopted. The latter study consists from three parts. The first part sheds a light on the manifestations of moderation in the Holy Quran. The second part sheds a light on the manifestations of moderation in Aqidah. The third part sheds a light on the manifestations of moderation in worships, ethics and Ahkam. It was found that the moderation ideology in Islam can manifest in all the aspects of life.

Al-Abdullah (2003) aimed to explore the role of the faculty members in Tiba University in promoting a moderate ideology among students. A descriptive approach was adopted. The sample consists from 163 faculty members. It was found that the role of those faculty members in promoting a moderate ideology among students is moderate. It was found that there are statistically significant differences between the respondents in terms of the extent of carrying out this role which can be attributed to major. The latter differences are for the favor of the ones who are specialized in education and Shariah. It was found that there are statistically significant differences between the respondents in terms of the extent of carrying out this role which can be attributed to gender. The latter differences are for the favor of males. It was found that that there isn't any statistically significant difference between the respondents in terms of the extent of carrying out this role which can be attributed to academic rank.

Al-Saeed (2005) aimed to develop a model for the Islamic education curricula of the primary school stage in Yemen in order to promote moderate ideologies among students. A descriptive analytical approach was adopted and a questionnaire was used. The population consists from all the Islamic education curricula of the primary school stage in Yemen. It was found that the latter books don't provide much attention to the Islamic education curricula to moderate ideologies. The latter researcher developed a matrix that involves moderate ideology that should be embedded in the latter curricula. He also developed a map for the concepts of moderation to be included in the Islamic education curricula of the primary school stage in Yemen

Al-Mousa (2008) aimed to explore the reality of moderation in the contemporary ideologies. He also aimed to identify the manifestations of moderation in the contemporary Arab ideologies. He aimed to identify the most important future challenges that may affect moderation. He aimed to develop a vision for fighting against radicalism and excessiveness. A descriptive analytical approach, and a historical approach were adopted. In addition, a comparative approach was adopted. It was found that moderation should be manifested in one's ideas. It was found that adopting a moderate ideology is determined based on the way one interacts with his family. It was found that the contemporary ideologies are characterized with being moderate.

Al-Omari (2009) conducted a study titled (Islam: the religion of moderation throughout ages). He adopted a descriptive analytical approach. He aimed to identify the way in which moderation is manifested in Islam. The first part of the study sheds a light on moderation and the second part sheds a light on the manifestations of moderation in Islam. The third part presents the interpretations of various texts in the Holy Quran and Sunah. Such interpretation proves that Islam aim at promoting moderation. The fourth part aims at showing the way of dealing with others in pursuant to the Holy Quran and Sunah. It was found that adopting a right moderate ideology requires understanding Quran and Sunah correctly.

Al-Bashry (2011) aimed to explore the role of university in promoting moderate ideologies among students through the activities conducted in the Islamic education course. His study is significant because it sheds a light on university as a leading educational institution that has important contributions. Such contributions are achieved through faculty members, curricula and activities. A descriptive inductive approach was adopted. The latter 
researcher found that universities aim at promoting moderation among students through activities and programs related to Islamic education. It was found that universities have been playing significant roles throughout several ages. It was found that universities play a significant role in serving society and protecting it from the spread of negative ideologies. It was found that universities play a significant role in promoting good ethics and ideologies. It was found that adopting Islam in manner that is not moderate shall hinder one from reflecting the true image about Islam. It was found that Islamic education plays a significant role in promoting moderate ideologies among students. That is done through carrying out several goal-oriented programs and activities.

Mohammad (2001) aimed to explore the effectiveness of a proposed program that aims at promoting moderate ideologies among female students through student activities. An experimental approach was adopted through dividing the sample into experimental and control groups. A thirty item questionnaire was used. This questionnaire sheds a light on two areas. It was found that the proposed program is effective in promoting moderate ideologies among female students through student activities.

Al-Shar'ah and Al-Bela'sy (2011) aimed to explore the extent of adopting moderate ideologies by faculty members. A descriptive approach was adopted. A twenty three item questionnaire was used. Questionnaire forms were distributed to 189 female students who were selected from Irbid University College and Balqa Applied University. It was found that the results related to intellectual aspects are similar to the ones related to behavioral aspects.

Hwari and Adoun (2012) aimed to explore the role of universities in promoting moderate ideologies through (faculty members, educational methods and establishing relationships with the members of the local community). A descriptive approach was adopted. A random sample was selected. It consists from 400 deans, vide deans, heads of department and vice heads of department. Questionnaire forms were distributed to the members of the selected sample. 368 forms are considered valid for analysis. 58\% of the respondents believe that there's a high need for activating the role of universities in promoting moderate ideologies and intellectual security among students. It was found that $6 \%$ of the students believe that is a low need for activating the role of universities in promoting intellectual security among students. It was found that $82 \%$ of the students have either moderate or much knowledge about the methods and procedures adopted for promoting moderate ideologies and intellectual security among students

Nibras and Ibrahim (2012) aimed to identify the attributes that should be possessed by the faculty member who want to promote moderate ideologies. A descriptive approach was adopted and a questionnaire was used to collect data. The sample consists from 36 faculty members. The questionnaire sheds a light on several attributes; (academic and professional attributes; personal attributes and social and cultural attributes). It was found that personal attributes are ranked first due to showing a mean of 100. It was found that the social and cultural attributes are ranked second due to showing a mean of 95.79. It was found that the academic and professional attributes are ranked third due to showing a mean of 93.71 .

Al-Jahni (2013) aimed to explore the extent of embedding moderate ideologies within the Islamic education curricula of the secondary stage. It aimed to explore the effectiveness of this curricula in promoting these ideologies. To meet the study's goals, a descriptive approach was adopted and a survey was used. In addition, content analysis was conducted. The sample consists from all the supervisors of the Islamic education course in Makkah, Saudi Arabia (26 supervisors). The latter study was conducted during the second semester of the academic year (2011-2012). It was found that the extent of embedding moderate ideologies within the Islamic education curricula of the secondary stage is high. It was found that this curricula play a moderate role in promoting these ideologies

Abu Jaber (2014) aimed to identify the role of faculty members in the Islamic University in Gaza in promoting moderate ideologies among students. A descriptive approach was adopted for meeting the study's goals. Forty three item questionnaire was used.. The sample consists from 333 female and male students who are either in their first year or fourth year. Those students were selected from the faculty of law, faculty of Shariah and faculty of engineering. The latter study was conducted during the second semester of the academic year (2013-2013). The sample was selected through using the random stratified sampling method. It was found that there isn't any statistically significant difference between the respondents' attitudes which can be attributed to gender. The latter attitudes are towards the role of faculty members in promoting moderate ideologies. It was found that there are statistically significant differences between the respondents' attitudes which can be attributed to faculty. . The latter differences are for the favor of the students enrolled at the faculty of Shariah and the ones enrolled at the faculty of law.

Gutkowski (2015) adds that the government plays a very important role in promoting moderate Islamic ideologies. He also adds that that the government plays a very important role in promoting peace and encourage people to have dialogue-related ethics.

Zamily (2017) aimed to explore the role of Muslim preachers and scholars in correcting wrong conceptions and promoting moderate ideologies. An analytical descriptive approach was adopted. It was found that Muslim preachers and scholars play a very significant role in correcting wrong conceptions and promoting moderate 
ideologies

Al-Shalash (2017) aimed to explore the role of Saudi private colleges and universities in promoting moderate ideologies. A descriptive approach was adopted and the relevant documents were analyzed. The latter researcher collected data from the relevant books, studies, and researcher. It was found that fighting radical ideologies requires promoting Islamic moderate ideologies. It was also found that Saudi private colleges and universities play a significant role in promoting moderate ideologies

According to Zuhdi (2018), curriculaand teachers play a significant role in shaping students' understanding for Islam. They also play a significant role inpromoting moderate Islamic ideologies. In order for curricula to promote such ideologies effectively, they must be adapted with the recent social changes. In order for curricula to promote such ideologies effectively, they must be provided with courses that aim at developing them professionally. Teachers must also have adequate information about sociology, politics, history, and information technology (IT) in order to promote moderate Islamic ideologies effectively (Zuhdi, 2018).

Ali (2018) aimed to explore the role of teaching English as a foreign language in promoting moderate Islamic ideologies. He used the observation method to collect data. He also collected data through conducting interviews. He found that teaching English as a foreign language be effectively used for promoting moderate Islamic ideologies among people

\section{Methods and procedures:}

\section{Approach}

A descriptive analytical approach was adopted by the researchers. This approach was adopted to explore the role of the faculties of Shariah in Jordanian public universities in promoting moderate ideologies among students. It is usually adopted when conducting in scientific research in the aim of providing a sensory description for things and objects. It is usually adopted for identifying whether certain sensory attributes of objects are accepted or not. It is also adopted to understand and explore variables and their constituents (Lawless and Heymann, 1999).

\section{Population and Sample:}

The population consists from all of the graduate students who are enrolled in the faculties of Shariah in Jordanian public universities. Based on the statistics issued by the Ministry of Higher Education for the year (2019-2020), the population consists form 750 students. A simple random sample was selected. It consists from 344 female and male students. Information about that is illustrated through the table below

Table (1): The distribution of the respondents in accordance with (gender, academic year and academic program)

\begin{tabular}{|l|l|r|r|}
\hline Variable & Category & Frequency & Percentage \\
\hline \multirow{5}{*}{ Gender } & Female & 177 & $51.5 \%$ \\
\cline { 2 - 4 } & Male & 167 & $48.5 \%$ \\
\cline { 2 - 4 } & Total & 344 & $100 \%$ \\
\hline \multirow{5}{*}{ Aniversity } & the university of Jordan, & 104 & $30.2 \%$ \\
\cline { 2 - 4 } & Yarmouk University & 135 & $39.2 \%$ \\
\cline { 2 - 4 } & Mu'tah University & 105 & $30.5 \%$ \\
\cline { 2 - 4 } & Total & 344 & $100 \%$ \\
\hline \multirow{3}{*}{ Academic program } & MA program & 180 & $52.3 \%$ \\
\cline { 2 - 4 } & PhD program & 164 & $47.7 \%$ \\
\cline { 2 - 4 } & Total & 344 & $100 \%$ \\
\hline
\end{tabular}

\section{The study's instrument:}

A questionnaire was developed based on the relevant studies. It consists from several items. Those items aim at exploring the role of the faculties of Shariah in Jordanian public universities in promoting moderate ideologies among students. They aim to explore this role in several areas: (teaching, scientific research, curricula, and training programs \&student activity). They aim to explore that from the graduate students' perspective. The preliminary version of the questionnaire consists from 54 items that shed a light on four(4) areas.

\section{The validity of the questionnaire}

To measure the validity of the questionnaire, the preliminary version of the questionnaire was passed to several experts who work as faculty members at Jordanian universities. To be specific, this version was passed to 15 experts. Those experts were asked to assess this version in terms of clarity, language and relevancy. The researchers decided to keep the items that are approved by $80 \%$ of the experts. In the light of the experts' opinions, some items were deleted and some language mistakes were corrected. The final version of the questionnaire consists from 48 items that shed a light on 4 areas. Information about that is listed below:

1- The teaching area: 13 items address this area 
2- The scientific research area: 10 items address this area

3- The curricula area: 16 items address this area

4- The training programs \& student activity area: 9 items address this area

\section{Validity of the questionnaire:}

The researchers measured the validity of the questionnaire through calculating the Cronbach Alpha coefficient values. It was found that the latter values are within the range of (0.86-0.95). Those values indicate that the questionnaire is reliable and provides accurate results. Table 2 presents those values Table (2): The Cronbach Alpha coefficient values

\begin{tabular}{|l|l|r|r|}
\hline No. & Area & \multicolumn{1}{|l|}{ Items } & The Cronbach Alpha coefficient value \\
\hline 1 & Teaching & 13 & 0.92 \\
\hline 2 & scientific research & 10 & 0.95 \\
\hline 3 & curricula & 16 & 0.86 \\
\hline 4 & training programs \& student activity & 9 & 0.95 \\
\hline
\end{tabular}

Classification of means:

The five point Likert scale was adopted: The categories of this scale are: strongly agree, agree, neutral, disagree, and strongly disagree. The scores that are represented by those categories are: 5, 4, 3, 2 and 1 respectively.

The interval between the categories used for classifying the means is calculated below:

(The maximum value-the minimum value) / (the number of the required categories)

$(5-1) /(3)=1.33$

The categories used for classifying the means are calculated below

Low: 2.33 or less

Moderate: $2.34-3.67$

High: 3.68 or more

The Study's variables:

The study's variables are listed below:

1- The mediating variables: Those variables are (gender, academic year and academic program)

2- The dependent variable: It's represented in the role of the faculties of Shariah in Jordanian public universities in promoting moderate ideologies among students from the graduate students' perspective. This variable is measured through calculating means.

\section{Statistical analysis:}

The researchers calculated the relevant means and standard deviations in order to provide answers to the study's questions:

\section{Results and discussion related to the study's question:}

What's the role of the faculties of Shariah in Jordanian public universities in promoting moderate ideologies from the perspective of graduate students?

To answer this question, means and standard deviations are calculated. Table (3)presents the results of this question: Table (3): The role of the faculties of Shariah in Jordanian public universities in promoting moderate ideologies from the perspective of graduate students

\begin{tabular}{|l|l|r|r|r|l|}
\hline No. & Area & Mean & \multicolumn{1}{l|}{ Std. } & \multicolumn{1}{l|}{ Rank } & \multicolumn{1}{l|}{ Degree } \\
\hline 3 & Curricula & 3.73 & .660 & 3 & High \\
\hline 1 & Teaching & 3.50 & .720 & 1 & Moderate \\
\hline 2 & scientific research & 3.44 & .780 & 2 & Moderate \\
\hline 4 & training programs \& student activity & 2.87 & 1.02 & 4 & Moderate \\
\hline & Total & 3.44 & .670 & & \multicolumn{2}{l}{ High } \\
\hline
\end{tabular}

It was found that the faculties of Shariah in Jordanian public universities play a moderate role in promoting moderate ideologies among students, because the total mean is 3.44. The total standard deviation is 0.670 .

The curricula area is ranked first due to showing a mean of 3.73 which is high. The standard deviation of the latter area is 0.660 . The teaching curricula is ranked second, due to showing a mean of 3.50 which is moderate. The standard deviation of the latter area is 0.720 . The scientific research area is ranked third due to showing a mean of 3.44 which is moderate. The standard deviation of the latter area is .0780.The (training programs \&student activity) area is ranked fourth due to showing a mean of 2.87 which is moderate. The standard deviation of the latter area is 1.02 .

Such a moderate role indicates that the faculties of Shariah in Jordanian public universities are in need for providing more attention to the promotion of moderate ideologies among students. It was found that the curricula area is ranked first. That indicates that the extent of embedding moderate Islamic ideologies in curricula is high. 
As for the other areas, they show moderate roles in promoting moderate ideologies among students

The results are consistent with the results concluded by Shalash (2017). The latter researcher suggests that colleges and universities play a moderate role in promoting moderate ideologies. The result related to the curricula area is inconsistent with the result concluded by Al-Jahni (2013). The latter researcher suggests that the extent of embedding moderate ideologies within the Islamic education curriculum of the second secondary grade is high. The results of the present study are consistent with the result of Al-Bashry (2011). The latter researcher found that universities play a significant role in promoting good ethics and ideologies. The results of the present study are consistent with the result of Zamily (2017). The latter researcher found that Muslim preachers and scholars play a very significant role in correcting wrong information and promoting moderate ideologies.

Means and standard deviations are calculated and presented below for each area:

First: The teaching area:

Table (4): The role of the faculties of Shariah in Jordanian public universities in promoting moderate ideologies through teaching

\begin{tabular}{|l|l|l|l|l|l|}
\hline No. & Statement & Mean & Std. & Rank & level \\
\hline 8 & $\begin{array}{l}\text { The faculty seeks promoting tolerance and moderate ideologies as } \\
\text { they are presented by Prophet Mohammad }\end{array}$ & 3.76 & 1.02 & 1 & Moderate \\
\hline 1 & During lectures, faculty members talk about moderate ideologies & 3.76 & .990 & 2 & Moderate \\
\hline 13 & $\begin{array}{l}\text { The faculty seeks identify the way in which the moderate ideologies } \\
\text { are embedded in the Islamic legislations }\end{array}$ & 3.56 & .960 & 3 & Moderate \\
\hline 5 & $\begin{array}{l}\text { Faculty members teach students information about the moderate } \\
\text { ideologies and their educational value }\end{array}$ & 3.51 & 1.02 & 4 & Moderate \\
\hline 12 & $\begin{array}{l}\text { The faculty seeks promoting moderate ideologies in various faculties } \\
\text { and assemblies }\end{array}$ & 3.51 & 1.00 & 5 & Moderate \\
\hline 7 & The curricula of the faculty aims at promoting moderate ideologies & 3.50 & 1.01 & 6 & Moderate \\
\hline 10 & The faculty seeks promoting moderate ideologies among students & 3.49 & .950 & 7 & Moderate \\
\hline 4 & $\begin{array}{l}\text { The faculty seeks developing the teaching skills that be used for } \\
\text { promoting moderate ideologies }\end{array}$ & 3.47 & 1.08 & 8 & Moderate \\
\hline 9 & $\begin{array}{l}\text { The faculty holds lectures and symposiums that identify the } \\
\text { manifestations of moderate ideologies }\end{array}$ & 3.46 & .960 & 9 & Moderate \\
\hline 6 & $\begin{array}{l}\text { The faculty provides much attention to the educational role of faculty } \\
\text { members in promoting moderate ideologies }\end{array}$ & 3.46 & 1.01 & 10 & Moderate \\
\hline 2 & Faculty members teach students how to promote moderate ideologies & 3.42 & .970 & 11 & Moderate \\
\hline 11 & $\begin{array}{l}\text { The faculty provides suitable solutions for some contemporary } \\
\text { problems hindering the promotion of moderate ideologies }\end{array}$ & 3.36 & 1.01 & 12 & Moderate \\
\hline 3 & Faculty members hold lectures about moderate ideologies & 3.26 & 1.07 & 13 & Moderate \\
\hline & Total & 3.50 & .720 & & Moderate \\
\hline
\end{tabular}

Based on table (4), the means are within the range of (3.26-3.76). Statement 8 is ranked first because its mean is 3.76 which is moderate. It states the following: (The faculty seeks promoting tolerance and moderate ideologies as they are presented by Prophet Mohammad). Statement 3 is ranked last because its mean is 3.26 which is moderate. It states the following: (faculty members hold lectures about moderate ideologies). The overall mean of the teaching area is 3.50 which is moderate.

The second area: The scientific research area:

Table (5): The role of the faculties of Shariah in Jordanian public universities in promoting moderate ideologies through scientific research

\begin{tabular}{|c|c|c|c|c|c|}
\hline No. & Statement & Mean & Std. & Rank & level \\
\hline 21 & $\begin{array}{l}\text { The faculty seeks publishing distinguished studies about the } \\
\text { manifestations of moderate ideologies }\end{array}$ & 3.53 & 1.03 & 1 & Moderate \\
\hline 19 & $\begin{array}{l}\text { The faculty provides support to the publication of studies about the } \\
\text { manifestations of moderate ideologies }\end{array}$ & 3.53 & 1.00 & 2 & Moderate \\
\hline 14 & $\begin{array}{l}\text { The faculty guides and direct researchers to show the moderate } \\
\text { ideologies in Islam }\end{array}$ & 3.50 & 0.98 & 3 & Moderate \\
\hline 22 & $\begin{array}{l}\text { The faculty seeks illustrating the opinions of contemporary scholars } \\
\text { and scholars in ancient times about moderate ideologies }\end{array}$ & 3.47 & 0.98 & 4 & Moderate \\
\hline 17 & $\begin{array}{l}\text { The faculty provides many reliable information sources that aim at } \\
\text { promoting moderate ideologies }\end{array}$ & 3.44 & 1.02 & 5 & Moderate \\
\hline 18 & $\begin{array}{l}\text { The faculty holds conferences that aim at addressing concepts and } \\
\text { requirements related to moderate ideologies }\end{array}$ & 3.43 & 1.04 & 6 & Moderate \\
\hline
\end{tabular}




\begin{tabular}{|r|l|r|r|r|c|}
\hline No. & Statement & Mean & Std. & Rank & level \\
\hline 16 & $\begin{array}{l}\text { The faculty encourages faculty members to continue doing studies } \\
\text { that aim at promoting moderate ideologies }\end{array}$ & 3.39 & 1.03 & 7 & Moderate \\
\hline 20 & $\begin{array}{l}\text { The faculty seeks shedding a light on the manifestations of } \\
\text { excessiveness and negligence that violate moderate ideologies }\end{array}$ & 3.38 & 0.98 & 8 & Moderate \\
\hline 23 & $\begin{array}{l}\text { The faculty teaches students how to refute the opinions that are } \\
\text { inconsistent with the moderate ideologies }\end{array}$ & 3.37 & 1.08 & 9 & Moderate \\
\hline 15 & $\begin{array}{l}\text { The faculty provides support to the studies related to moderate } \\
\text { ideologies }\end{array}$ & 3.34 & 0.92 & 10 & Moderate \\
\hline & Total & 3.44 & 0.78 & & Moderate \\
\hline
\end{tabular}

Based on table (5), the means are within the range of (3.34-3.53). Statement 21 is ranked first because its mean is 3.53which is moderate. It states the following: (The faculty seeks publishing distinguished studies about the manifestations of moderate ideologies). Statement 15 is ranked last because its mean is 3.34 which is moderate. It states the following: (The faculty provides support to the studies related to moderate ideologies). The overall mean of the scientific research area is 3.44 which is moderate.

The third area: The curricula

Table (6): The role of the faculties of Shariah in Jordanian public universities in promoting moderate ideologies through curricula

\begin{tabular}{|c|c|c|c|c|c|}
\hline No. & Statement & Mean & Std. & Rank & level \\
\hline 27 & Curricula seeks promoting moderate ideologies & 3.91 & 0.92 & 1 & High \\
\hline 26 & $\begin{array}{l}\text { Curricula participate in fighting against the misinterpretation of } \\
\text { religious texts }\end{array}$ & 3.89 & 0.93 & 2 & High \\
\hline 36 & $\begin{array}{l}\text { Curricula include facts, proofs and Quranic verses about moderate } \\
\text { ideologies }\end{array}$ & 3.83 & 0.93 & 3 & High \\
\hline 25 & $\begin{array}{l}\text { Curricula present Shariah-based proofs that aim at fighting against } \\
\text { fanaticism }\end{array}$ & 3.81 & 0.90 & 4 & High \\
\hline 35 & $\begin{array}{l}\text { Curricula aim at illustrating the manifestations of moderate } \\
\text { ideologies in the Holy Quran and Sunah }\end{array}$ & 3.79 & 0.97 & 5 & High \\
\hline 38 & $\begin{array}{l}\text { Curricula are developed based on the moderate Islamic ideologies } \\
\text { and the opinions of the Muslim scholars }\end{array}$ & 3.76 & 0.96 & 6 & Moderate \\
\hline 34 & $\begin{array}{l}\text { Curricula encourage students and faculty members to invest their } \\
\text { potentials and efforts in promoting moderate ideologies }\end{array}$ & 3.76 & 0.94 & 7 & Moderate \\
\hline 31 & $\begin{array}{l}\text { Curricula encourage students and faculty members to invest their } \\
\text { potentials and efforts in doing good deeds }\end{array}$ & 3.74 & 0.93 & 8 & Moderate \\
\hline 37 & $\begin{array}{l}\text { Curricula present models of contemporary scholars and scholars in } \\
\text { ancient times who adopt moderate ideologies }\end{array}$ & 3.71 & 0.94 & 9 & Moderate \\
\hline 32 & $\begin{array}{l}\text { Curricula identify the negative impacts of deviant ideologies which } \\
\text { contradict the moderate ideologies }\end{array}$ & 3.70 & 0.97 & 10 & Moderate \\
\hline 24 & $\begin{array}{l}\text { Curricula aim at illustrating the moderate ideologies that are } \\
\text { manifested in Islam }\end{array}$ & 3.67 & 0.91 & 11 & Moderate \\
\hline 33 & $\begin{array}{l}\text { Curricula aim at identifying the approach to be adopted for fighting } \\
\text { against ignorance }\end{array}$ & 3.67 & 0.91 & 12 & Moderate \\
\hline 39 & $\begin{array}{l}\text { Curricula aim at identifying radical and deviant ideologies that } \\
\text { contradict moderate ideologies }\end{array}$ & 3.66 & 0.95 & 13 & Moderate \\
\hline 29 & $\begin{array}{l}\text { Curricula provide feedback that correct any misconception related to } \\
\text { moderate ideologies }\end{array}$ & 3.63 & 0.93 & 14 & Moderate \\
\hline 28 & $\begin{array}{l}\text { Curricula include student activities that aim at promoting moderate } \\
\text { ideologies }\end{array}$ & 3.59 & 0.97 & 15 & Moderate \\
\hline 30 & $\begin{array}{l}\text { Curricula employ educational methods that aim at promoting } \\
\text { moderate ideologies }\end{array}$ & 3.48 & 0.98 & 16 & Moderate \\
\hline & Total & 3.73 & .660 & & High \\
\hline
\end{tabular}

Based on table (6), the means are within the range of (3.48-3.91). Statement 27 is ranked first because its mean is 3.91which is high. It states the following: (Curricula seeks promoting moderate ideologies). Statement 30 is ranked last because its mean is 3.48 which is moderate. It states the following: (Curricula employ educational methods that aim at promoting moderate ideologies). The overall mean of the curricula area is $3.73 \mathrm{which}$ is high. The fourth area: Training programs \& student activity 
Table (7): The role of the faculties of Shariah in Jordanian public universities in promoting moderate ideologies through training programs \& student activity

\begin{tabular}{|c|c|c|c|c|c|}
\hline No. & Statement & Mean & Std. & Rank & level \\
\hline 46 & $\begin{array}{l}\text { The faculty encourages students to promote the Islamic moderate } \\
\text { ideologies among the people in their communities }\end{array}$ & 3.10 & 1.27 & 1 & Moderate \\
\hline 48 & The faculty & 3.01 & 1.18 & 2 & Moderate \\
\hline 42 & The faculty & 2.97 & 1.18 & 3 & Moderate \\
\hline 41 & The faculty & 2.92 & 1.16 & 4 & Moderate \\
\hline 40 & $\begin{array}{l}\text { The faculty holds training courses for students about the way of } \\
\text { promoting moderate ideologies }\end{array}$ & 2.90 & 1.20 & 5 & Moderate \\
\hline 47 & $\begin{array}{l}\text { The faculty provides students with training courses about the way } \\
\text { of writing bulletins about moderate ideologies }\end{array}$ & 2.87 & 1.14 & 6 & Moderate \\
\hline 45 & $\begin{array}{l}\text { The faculty seeks publishing the studies conducted by students } \\
\text { about issues related to the Islamic moderate ideologies }\end{array}$ & 2.79 & 1.19 & 7 & Moderate \\
\hline 44 & $\begin{array}{l}\text { The faculty seeks publishing the audio and written material } \\
\text { developed by students about the Islamic moderate ideologies }\end{array}$ & 2.74 & 1.27 & 8 & Moderate \\
\hline \multirow[t]{2}{*}{43} & $\begin{array}{l}\text { The faculty holds training courses for parents about the way of } \\
\text { raising up their sons and daughters and fighting against radicalism }\end{array}$ & 2.54 & 1.26 & 9 & Moderate \\
\hline & Total & 2.87 & 1.02 & & Moderate \\
\hline
\end{tabular}

Based on table (7), the means are within the range of (2.54-3.10). Statement 46 is ranked first because its mean is 3.10 which is moderate. It states the following (The faculty encourages students to promote the Islamic moderate ideologies among the people in their communities). Statement 43 is ranked last because its mean is 2.54which is moderate. It states the following: (The faculty holds training courses for parents about the way of raising up their sons and daughters and fighting against radicalism). The overall mean of the training programs \& student activity area is 2.87 which is moderate.

\section{Conclusion and Recommendations:}

Through analyzing data, it was found that the faculties of Shariah in Jordanian public universities play a moderate role in promoting moderate ideologies among students, because the total mean is 3.44 . That indicates that the decision makers in the latter faculties must provide more attention to the promotion of such ideologies. It also indicates that the latter faculties must take effective measures to fight against the radical strategies that have been widely spreading among university students. The curricula area is ranked first due to showing a mean of 3.73 which is high. The teaching curricula is ranked second, due to showing a mean of 3.50 which is moderate. The scientific research area is ranked third due to showing a mean of 3.44 which is moderate. The (training programs \&student activity) area is ranked fourth due to showing a mean of 2.87 which is moderate. That indicates that the latter faculties must increase the number of the training programs \&student activities that aim at fighting against the radical strategies that have been widely spreading among university students

\section{In the light of the study's results, the researchers recommend:}

Activating the role of the faculties of Shariah in Jordanian public universities in promoting moderate ideologies among students. Such activation must involve several areas: (teaching, scientific research, curricula, and training programs \&student activity).

Increasing the cooperation between the faculties of Shariah in Jordanian universities in order to suggest practical solutions for addressing the problems hindering those universities from promoting moderate ideologies among students.

- Searching for new methods that enable the faculties of Shariah in Jordanian universities to promote moderate ideologies among students. Such methods should target several area; (teaching, scientific research, curricula, and training programs \&student activity).

\section{References}

The Holy Quran

Al-Ameery, Omar Baha' Al-Deen (2007). The moderate ideologies of Islam and the Islamic nation under Fiqh. Al-Thaqafah publishing and distribution house. Doha Qattar.

Abu Al-Hasan, Ibrahim (2015). Moderation in Islam. Horas Al-Dawleye publishing and distribution house. Alexandria. Egypt

Badawi, Abed Al-Rahman (1999). Schools of Islamic jurisprudence. Dar Al-Elem lel Malayeen publishing and distribution house. Beirut. Lebanon.

Al-Bura'y, Wafa' (2002). The role of university in fighting against intellectual radicalism. Dar Al-Ma'refeh 
publishing and distribution house. Alexandria. Egypt

Al-Bashry, Ayesh (2011). The role of university in promoting moderate ideologies among students through activities in the Islamic education course. The proceedings of a conference titled (The role of Arab universities in promoting moderate ideologies among young Arab people). Almadinah Al-Munawarah, Saudi Arabia. 69/March/2011.

Husam, Mohammad and Ma'bad, Fathi (2003). The role of institutions in fighting against student violence in the light of the contemporary challenges. The proceedings of the second scientific annual conference which is titled (Future visions for developing education in the light of the contemporary challenges). Ain Shmas University. Cairo. Egypt. P.288

Al-Khayat, Abed Al-Aziz (1994). The ethics governing dialogue. The publications of the Ministry of Culture. Amman. Jordan

Zamily, Zakareya Ibrahim (2017). The role of Muslim preachers and scholars in correcting wrong conceptions and promoting moderate ideologies. The proceedings of the second scientific annual conference which is titled: (Misconceptions and its relationship with violence and radicalism. This conference was held by the Ministry of Awqaf and Religious Affairs and the Islamic University in Gaza. Palestine.

Al-Sultani, Abu Hurrah (2011).Integrity and moderation. The Journal of Moderation. The Global Forum of Moderation. Amman. Jordan. First issue.

Al-Shar'ah, Naser and Al-Bela'sy, Soud (2011). The manifestations of moderation the character of faculty member. The proceedings of a conference titled (The role of Arab universities in promoting moderate ideologies among young Arab people). Almadinah Al, Munawarah, Saudi Arabia. 6-9/March/2011

Al-Shalash, Abed Al-Rahman (2017). The role of Saudi private colleges and universities in promoting moderate ideologies (Reality and aspirations). The proceedings of a conference held at Naif Arab University for Security Sciences, Reyad. Saudi Arabia

Asalabi, Ali (2001). The manifestations of moderation in the Holy Quran. Al-Sahabeh Library. Al-Shareqah. UAE.

E'baidat, Sulaiman Ahmad (2014).Methods for teaching Islamic education course. Al-Feker publishing and distribution house. Beiruit. Lebanon

Al-Omari, Akram Diya' (2009). Islam: the religion of moderation throughout ages. Al-Elem publishing and distribution house. Beiruit. Lebanon

Al-Farfour, Mohammad Abed Al-Latif (2002).Moderation in Islam. Al-Nafa'es publishing and distribution house. Beiruit. Lebanon.

Mohammad, Rasha (2011). Promoting moderate ideologies among female university students and its role in increasing their engagement in student activities. The proceedings of a conference titled (The role of Arab universities in promoting moderate ideologies among young Arab people). Almadinah Al, Munawarah, Saudi Arabia. 6-9/March/2011.

Almasri, Mohammad Amin (2001). The factors negatively affecting the Islamic society. Al-Ketab Al-Jame'e publishing and distribution house. Damascus. Syria.

Al-Maqousi, Yaseen and Fatheye, Fateheye(2013). The extent of embedding ideologies of tolerance in the Islamic education curricula of the primary school stage in Jordan. The Educational and Psychological Journal of the Islamic University. The Islamic Science University. 21(4). 129-155

Al-Mudwadi, Abu Al-A'la(1986). The role of students in developing the future of the Islamic World. Al-Resale publishing and distribution house. Biuret. Lebanon.

Nawab Al-Deen, Abed Al-Rab (1995). Advice: Conditions and ethics. Al-Dar Al-Shameye publishing and distribution house. Biuret. Lebanon.

Al-Abdullah, Mohammad (2003). The role of the faculty members in Tiba University in promoting a moderate ideology among students. Tiba University. Almadinah Al-Munawarah, Saudi Arabia.

Al-Saeed, Mohammad (2005). Designing a model for the Islamic education curricula of the primary school stage in Yemen. PhD dissertation. Ta'z University. Yemen.

Al-Mousa, Saeed (2008). Moderation in the contemporary ideologies and the future challenges. Al-Feker publishing and distribution house. Beiruit. Lebanon.

Hwari, Me'raj and Adoun, Naser (2012). The role of universities in promoting moderate ideologies and intellectual security among students: A field study targeting the University of Laghouat in Algeria. The proceedings of a conference titled (The role of Arab universities in promoting moderate ideologies among young Arab people). Almadinah Al, Munawarah, Saudi Arabia. 6-9/March/2011

Al-Jahni, Ali (2013).The effectiveness of the role of the Islamic education curricula of the secondary stage in promoting moderate ideologies among students. Unpublished MA thesis. Um Alqurah University. Saudi Arabia

Abu Jaber, Adnan (2014). The role of faculty members in the Islamic University in Gaza in promoting moderate ideologies among students and the methods of activating this role. Unpublished MA thesis. The Islamic University in Gaza. Gaza 
Ali, Fachr (2018). Incorporating Values of Moderate Islam for the 21st Century Learners in an English as a Foreign Language Class. Edukasia Islamika, 3(1).

Available at: <http://e-journal.iainpekalongan.ac.id/index.php/edukasiaislamika/article/view/1676>

Gutkowski, S. (2015). We are the very model of a moderate Muslim state: The Amman Messages and Jordan's foreign policy. International Relations. 30(2).

Lawless H.T., and Heymann H. (1999) Descriptive Analysis. In: Sensory Evaluation of Food. Food science text series. Springer, Boston, MA

Zuhdi, M. (2018). Challenging Moderate Muslims: Indonesia's Muslim Schools in the Midst of Religious Conservatism. Religions. 9(310).

Acknowledgment:

The researchers of the present study would like to thank Princess Rahma College for providing them with support. They would like to thank their families for providing them with much support. 